\title{
Combination of Azospirillum brasilense and Bradyrhizobium japonicum in the promotion of initial corn growth
}

\section{Gabriel Monteiro Aguiar Pereira1, Renato de Carvalho Menezes², Marcos Gomes da Cunha², Renato Carrer Filho ${ }^{2}$}

\author{
${ }^{1}$ UNIGOIÁS, Centro Universitário de Goiás, Goiânia, Goiás, Brasil. E-mail: gabriel.agro2015@ hotmail.com \\ ${ }^{2}$ Universidade Federal de Goiás, Campus Samambaia, Goiânia, Goiás, Brasil. E-mail: renato_cmenezes@hotmail.com, mgc@ufg.br, \\ carrerfilho@hotmail.com
}

Received: 26/07/2020; Accepted: 17/12/2020.

\begin{abstract}
Biological formulations used as inoculants are increasingly present in grasses, especially in corn. Positive results in promoting plant growth, with different associations with diazotrophic bacteria, show these capacities of interaction to act as plant growth regulators, making it a promising alternative with a low environmental impact. Thus, this study aimed to evaluate the efficiency of inoculation and co-inoculation of nodulating and non-nodulating diazotrophic bacteria as promoters of initial growth in corn plants. Therefore, the bacteria Azospirillum brasilense (UFG21 strain), Bradyrhizobium japonicum (commercial product), and their co-inoculation were used in seed treatment. The evaluations consisted of growth measuring of the root system and shoot and evaluating leaf chlorophyll concentration. The results showed a beneficial interaction between the bacteria and the corn plant, with an increase in the root system and chlorophyll content, compared to the control treatment.
\end{abstract}

Keywords: Biological nitrogen fixation, Inoculants, Symbiosis.

\section{Combinação de Azospirillum brasiliense e Bradyrhizobium japonicum na promoção de crescimento inicial do milho}

\section{RESUMO}

Formulações biológicas utilizadas como inoculantes estão cada vez mais presentes em gramíneas, especialmente na cultura do milho. Resultados positivos na promoção de crescimento de plantas, com diferentes associações com bactérias diazotrófias, mostram a capacidade dessas interações em agirem como reguladores de crescimento de plantas, o que torna uma alternativa promissora e de baixo impacto ambiental. Assim, o objetivo deste trabalho foi avaliar a eficiência da inoculação e co-inoculação de bactérias diazotróficas nodulantes e não nodulantes, como promotoras de desenvolvimento inicial em plantas de milho. Desse modo, as bactérias Azospirillum brasilense cepa UFG21, Bradyrhizobium japonicum (produto comercial) e a co-inoculação destas foram utilizadas no tratamento de sementes. As avaliações consistiram da mensuração de crescimento do sistema radicular e da parte aérea, além de verificar a concentração de clorofila nas folhas. Os resultados demonstraram interação benéfica quando da associação entre as bactérias e a planta de milho, com incremento do sistema radicular e do teor de clorofila, em relação ao tratamento controle.

Palavras-chave: Fixação biológica de nitrogênio, Inoculantes, Simbiose. 


\section{Introduction}

Corn (Zea mays L.) is one of the crops with great economic insertion in producing countries due to its good adaptability to growing regions and high commercial demand. The cultivation of corn goes through significant technological scope changes, increasing the yield (Paes et al., 2018). Concomitantly, the use of biological techniques that make it possible to reduce yield losses, increase nitrogen fixation efficiency and increase tolerance to climatic stresses are on the rise (Hungria et al., 2010; Martins et al., 2018).

In this scenario, works with beneficial associative diazotrophic bacteria have been reported (Barassi et al., 2008) being appreciated not only for co-inoculations with other prokaryotes but also for their ability to form nodules in leguminous plants. This co-inoculation can enhance desirable agronomic traits for the crop, such as increasing biomass and tolerance to edaphoclimatic stresses besides promoting biological nitrogen fixation (Dardanelli et al., 2008).

Among the native bacteria, Azospirillum species stand out, used as inoculants, either via seeds, sowing furrows, or dispensed directly in higher plants' phylloplane (Reis Junior et al., 2008; Czarnes et al., 2020). In this sense, studies using Azospirillum spp. have shown an increase in dry mass yield, nutrient accumulation in inoculated plants, and corn grain productivity (Bashan et al., 2006; Perrig et al., 2007; Hungria et al., 2010; Rozier et al., 2019).

At the same time, co-inoculation between bacterial species, such as Rhizobium sp., Azotobacter sp., Pseudomonas sp., Bacillus sp., and others, have shown various benefits in plants and cultivations systems, such as the crops succession between leguminous and grassy plants or, in a consortium system between grasses and forages (Cassan et al., 2009; Marks et al., 2015; Kalantari et al., 2018).

Thus, this study aimed to evaluate the initial growth of corn plants through the inoculation and co-inoculation of seeds with Azospirillum brasilense and Bradyrhizobium japonicum, both individually and jointly.

\section{Material and Methods}

The experiment was conducted under protected cultivation conditions in a greenhouse at the Centro Universitário de Goiás Uni-Anhanguera, Goiânia, GO, Brazil. In this work, we used the bacteria Bradyrhizobium japonicum, commercial inoculant $\mathrm{ATMO}^{\circledR}$, and Azospirillum brasilense, strain UFG21, belonging to the collection of bacteria from the Research Center in Phytopathology of the Federal University of Goiás, Goiânia, GO, Brazil.

The bacteria A. brasilense UFG21 was cultivated and multiplied in Petri dishes containing the 523 medium (Kado and Heskett, 1970) and incubated in a growth chamber for 48 hours, at $28{ }^{\circ} \mathrm{C}$. Bacterial suspensions used for the bioassays were made with $0.85 \% \mathrm{NaCl}$ saline solution and concentration adjusted to $\mathrm{OD}_{540}=0.4$, with the aid of a spectrophotometer (Romeiro, 2007), corresponding to approximately $1 \mathrm{x}$ $10^{9} \mathrm{CFU} \mathrm{mL}^{-1}$. Sterile saline solution, used for resuspension of bacterial isolates, was used as a control. The liquid inoculant $\mathrm{ATMO}^{\circledR}$, with a concentration of 5 $\mathrm{x} \quad 10^{9}$ CFU $\mathrm{mL}^{-1}$, was used according to the manufacturer's recommended dosage, with $100 \mathrm{~mL} 50$ $\mathrm{kg}^{-1}$ of seeds.

To test the compatibility between the strains of bacteria studied, an antibiogram test was performed, as described by Mafia et al. (2007), with modifications. The two bacteria were cultured as previously described, and a $100 \mu \mathrm{L}$ aliquot of each bacterial suspension was spread using a Drigalski spatula on the surface of the 523 medium. Immediately afterward, sterile $5 \mathrm{~mm}$ diameter filter paper discs were immersed in each of the two bacterial suspensions and dried for 15 minutes. Then, four discs of each bacterium were placed in contact with a bacterium on the surface of the Petri dish with the NA medium. For each combination, there were four replications, represented by a Petri dish. Petri dishes were placed at $28{ }^{\circ} \mathrm{C}$ and evaluated qualitatively in 48 hours as compatible or incompatible, attending to the presence of inhibition zones around the discs.

For the bioassay, in a greenhouse with controlled parameters of the average temperature $\left(30{ }^{\circ} \mathrm{C} \pm 5{ }^{\circ} \mathrm{C}\right)$ and relative humidity (50-70\%), the effect of inoculated bacteria acting as promoters of initial corn growth was evaluated. In this test, the experiment was installed in a completely randomized design, with ten replications and two plants per plot. The treatments consisted of T1: seeds treated with B. japonicum; T2: microbiolized seeds by soaking, for one hour, in a suspension of propagules of A. brasilense (Carrer Filho et al., 2015); T3: microbiolized seeds by $A$. brasilense and treated with $B$. japonicum; and T4: seeds immersed in sterile saline solution without bacteria. BRS-1051 corn seeds were treated with propagules of each bacteria and sown in $4.5 \mathrm{~L}$ pots containing autoclaved Bioflora ${ }^{\circledR}$ substrate, containing pine bark, vermiculite, and coconut fiber. In each pot, four seeds were sown at a depth of $3 \mathrm{~cm}$, and, after emergence, two seedlings were thinned.

At 15 days after sowing, the evaluations included measuring the stem base area and 30 days after sowing, the quantification of chlorophyll content. At 40 days after sowing, the weight of fresh and dry matter of the plants' root and aerial part was measured.

A manual caliper was used (Universal Caliper 150 $\mathrm{mm}$ in Carbon Steel - KINGTOOLS-500150) to measure the stem diameter. The measurements were taken at $2 \mathrm{~cm}$ from the stem base, obtaining the highest 
and lowest averages for calculating the stem base area. For the chlorophyll content, a portable chlorophyll meter (KONICA MINOLTA MODEL SPAP502) was used, performing two readings per plant, using the sixth fully expanded leaf in the middle of the leaf blade.

The corn plants were cut 40 days after sowing to obtain the plant fresh and dry matter of the shoot and root system, being both parts separated. After drying in an air-forced circulation oven for 72 hours at a temperature of $70{ }^{\circ} \mathrm{C}$, the samples were weighed to quantify the dry matter of shoot (DMAP) and root system (DMRS).

The analyzed variables were submitted to the analysis of variance using the R-Statistical software for statistical analysis. When the treatment was significant, the means were compared by the Tukey test at $5 \%$ probability.

\section{Results and Discussion}

The co-inoculation of $A$. brasilense UFG21 and $B$. japonicum showed the ability to promote the development of corn plants compared to plants from seeds without inoculation. Increased root system growth was observed in plants from seeds with A. brasilense strain UFG21 and/or B. japonicum. When inoculating the bacteria tested separately, they showed simultaneously positive results, but with less root development, assessed through the root system dry matter and compared with co-inoculation. Thus, an increase of about $100.0 \%$ in the root dry matter was observed compared to the control, resulting from the combination of the bacteria in corn seed treatment (Table 1). Regarding the shoot fresh and dry matter, there was no significant difference between the control and the treatments with plants from seeds inoculated with bacteria (Table 1).

Regarding the averages of the corn stem base area, there was no significant difference among treatments measured 15 days after sowing (Table 2). The nonsignificance is probably due to the short time between sowing and measuring the stem base area since there is a relationship with the nitrogen accumulation in this region (Duarte et al., 2003).

As for the chlorophyll content, there was a significant difference between the means of treatments from seeds inoculated with bacterial agents and the control treatment (Table 2).

For the compatibility test between bacteria, the formation of inhibition halo was not observed, which reports that these microorganisms are not antagonistic to each other, making it possible to co-inoculate these strains, a trend demonstrated in recent decades (Cassan et al., 2009; Kalantari et al., 2018).

Bacteria from the Azospirillum genus have been reported to produce phytohormones that stimulate root growth and promote leaves' photosynthetic parameters improvement, including the content of chlorophyll a, b, proline, and auxiliary photoprotective pigments, such as violaxanthin, zeaxanthin, antheraxanthin, lutein, neoxanthin, and beta-carotene. The rise in the concentration of these compounds results in greener plants without water stress in the aerial part, besides having the intrinsic capacity to colonize the root system of grasses and establish mutualistic and associative relationships with the host (Bashan et al., 2006; Cassan et al., 2009; Marchetti and Barp, 2015). Bacteria of the genus Bradyrhizobium, which act as nodule-forming, also perform biological nitrogen fixation by symbiosis in leguminous plants (Melo and Zilli, 2009).

Table 1. Root fresh matter (RFM), root dry matter (RDM), shoot fresh matter (SFM), and shoot dry matter of corn plants 36 days after sowing.

\begin{tabular}{lcccc}
\hline Treatment & RFM $(\mathbf{g})^{*}$ & RDM $(\mathbf{g})^{*}$ & SFM $(\mathbf{g})^{*}$ & SDM $(\mathbf{g})^{*}$ \\
\hline Control & $29.40 \mathrm{~b}$ & $12.19 \mathrm{c}$ & $82.67 \mathrm{a}$ & 48.99 a \\
A. brasilense & $40.07 \mathrm{a}$ & $12.79 \mathrm{bc}$ & $85.80 \mathrm{a}$ & $45.25 \mathrm{a}$ \\
B. japonicum & $27.64 \mathrm{~b}$ & $15.63 \mathrm{~b}$ & $91.21 \mathrm{a}$ & $48.98 \mathrm{a}$ \\
$($ B. japonicum + A. brasilense $)$ & $37.37 \mathrm{ab}$ & $23.84 \mathrm{a}$ & $80.43 \mathrm{a}$ & $44.62 \mathrm{a}$ \\
\hline CV $(\%)$ & 41.96 & 16.08 & 29.83 & 20.95 \\
\hline
\end{tabular}

*Means followed by the same letter in the columns do not differ by the Tukey test at $5 \%$ significance.

Table 2. Stem base area in corn plants, measured 15 days after sowing, and chlorophyll content, measured 30 days after sowing.

\begin{tabular}{lcc}
\hline Treatment & Stem base area $\left(\mathbf{c m}^{\mathbf{2}}\right)^{*}$ & Chlorophyll content* \\
\hline Control & $2.07 \mathrm{a}$ & $32.43 \mathrm{~b}$ \\
A. brasilense & $2.48 \mathrm{a}$ & $37.54 \mathrm{a}$ \\
B. japonicum & $2.13 \mathrm{a}$ & $41.11 \mathrm{a}$ \\
(B. japonicum + A. brasilense $)$ & $2.28 \mathrm{a}$ & $39.05 \mathrm{a}$ \\
\hline CV $(\%)$ & 23.54 & 12.68 \\
\hline
\end{tabular}

*Means followed by the same letter in the columns do not differ by the Tukey test at $5 \%$ significance. 
When performed with both species of bacteria, the inoculation of corn seeds shows synergism in the coinoculation, with the effect in promoting root growth, which may influence the increase in tolerance to water and nutritional stress, and yield increase. Cassan et al. (2009) report that the increase in development during the seedling stage may be due, in part, to the differential development of the embryo induced by bacterial growth regulators, which penetrate the seed lining together with water and accelerate root growth with concomitant increases in water and mineral uptake.

Similar studies have also obtained an increase in plants, as well as in the accumulation of biomass in the root system (Barassi et al., 2008). In wheat, the ability provided by the inoculation of $A$. brasilense induced "in situ" production of indole-acetic acid by colonizing the root system, contributing to the production of phytohormones (Rothballer et al., 2005). When studying the action of symbiotic bacteria, Noel et al. (1996) described a significant root increase in non-leguminous plants after seed inoculation with the Rhizobiaceae bacteria family, attributing this effect to bacterial phytohormones production.

The current study reports that the co-inoculation of non-symbiotic diazotrophic bacteria (Azospirillum sp.) and nodulating bacteria (Bradyrhizobium sp.) can favor the increase in yield and mitigate adverse climatic effects by expressing the increase in the root system and promoting the growth of the seedling, both in legumes, also having a role in grass development promotion (Cassan et al., 2009).

\section{Conclusions}

Co-inoculation of Azospirillum brasilense and Bradyrhizobium japonicum, via seed treatment, influences the initial development of the root system of corn plants by increasing the root dry matter and chlorophyll content in plants.

\section{Authors' Contribution}

Gabriel Monteiro Aguiar Pereira: experiment conduction and manuscript writing;

Renato de Carvalho Menezes: data analysis and results interpretation;

Marcos Gomes da Cunha: co-orientation and manuscript revision;

Renato Carrer Filho: orientation, planning, and manuscript revision.

\section{Bibliographic References}

Barassi, C.A., Sueldo, R.J., Creus, C.M., Carrozzi, L.E., Casanovas, W.M., Pereyra, M.A. 2008. Potencialidad de
Azospirillum en optimizer el crecimiento vegetal bajo condiciones adversas. In: Cassan, F.D., Garcia de Salamone, I. Azospirillum sp.: cell physiology, plant interactions and agronomic research in Argentina. Asociación Argentina de Microbiologia, Argentina, p. 49-59.

Bashan, Y., Bustillos, J.J., Leyva, L.A., Hernandez, J.P., Bacilio, M. 2006. Increase in auxiliary photoprotective photosynthetic pigments in wheat seedlings induced by Azospirillum brasilense. Biology and Fertility of Soils, 42, 279-285. DOI: 10.1007/s00374-005-0025-x.

Carrer Filho, R., Dianese, E.C., Cunha, M.G. 2015. Supressão da murcha de fusário em tomateiro por rizobactérias do gênero Bacillus. Pesquisa Agropecuária Tropical, 45(3), 356-363. DOI: 10.1590/1983-40632015v4535397.

Cassan, F., Perrig, D., Sgroy, V., Masciarelli, O., Penna, C., Luna, V. 2009. Azospirillum brasilense Az39 and Bradyrhizobium japonicum E109, inoculated singly or in combination, promote seed germination and early seedling growth in corn (Zea mays L.) and soybean (Glycine max L.). European Journal of Soil Biology, 45(1), 28-35. DOI: 10.1016/j.ejsobi.2008.08.005.

Czarnes, S., Marcier, P.E., Lemoine, D.G., Hamzaoui, J., Legendre, L. 2020. Impact of soil water content on maize responses to the plant growth-promoting rhizobacterium Azospirillum lipoferum CRT1. Journal of Agronomy and Crop Science, 206(5), 505-516. DOI: https//doi.org/10.111/jac.12399.

Dardanelli, M.S., Cordoba, F.J.F, Espuny, M.R., Rodriguez carvajal, M.A., Soria Diaz, M.E., Serrano, A.M.G., Okon, Y., Megias, M. 2008. Effect of Azospirillum brasilense coinoculated with Rhizobium on Phaseolus vulgaris flavonoids and Nod factor production under salt stress. Soil Biology \& Biochemistry, 40(11), 2713-2721. DOI: 10.1016/j.soilbio.2008.06.016.

Duarte, A.P., Kiehl, J.C., Camargo, M.A.F., Reco, P.C. 2003. Acúmulo de matéria seca e nutriente em cultivares de milho originário de clima tropical e introduzido de clima temperado. Revista Brasileira de Milho e Sorgo, 2(3), 1-20. DOI: 10.18512/1980-6477/rbms.v2n3p1-20.

Hungria, M., Campo, R.J., Souza, E.M., Pedrosa, F.O. 2010. Inoculation with selected strains of Azospirillum brasilense and A. lipoferum improves yields of maize and wheat in Brazil. Plant and Soil, 331(1), 413-425. DOI: https://doi.org/10.1007/s11104-009-0262-0.

Kado, C.I., Heskett, M.G. 1970. Selective Media for Isolation of Agrobacterium, Corynebacterium, Erwinia, Pseudomonas, and Xanthomonas. Phytopathology, 60(6), 969-976. DOI: 10.1094/Phyto-60-969.

Kalantari, S., Marefat, A., Naseri, B., Hemmati, R. 2018. Improvement of bean yield and Fusarium root rot biocontrol using mixtures of Bacillus, Pseudomonas and Rhizobium. Tropical Plant Pathology, 43(6), 499-505. DOI: https://doi.org/10.1007/s40858-018-0252-y.

Mafia, R.G., Alfenas, A.C., Maffia, L.A., Ferreira, E.M., Siqueira, L. 2007. Compatibility among rhizobacteria isolates and effect of mixture of isolates in inducing rooting and growth of eucalyptus clones. Árvore, 31(4), 635-643. DOI: https://doi.org/10.1590/S0100-67622007000400008. 
Marchetti, M.M., Barp, E.A. 2015. Efeito rizosfera: a importância de bactérias fixadoras de nitrogênio para o solo/planta. $\quad$ Ignis, $4(1), \quad 61-71 . \quad$ DOI: http://periodicos.uniarp.edu.br/index.php/ignis/article/view/76 7.

Marks, B.B., Megias, M., Ollero, F.J., Nogueira, M.A., Araujo, R.S., Hungria, M. 2015. Maize growth promotion by inoculation with Azospirillum brasilense and metabolites of Rhizobium tropici enriched on lipo-chitooligosaccharides (LCOs). AMB Express, 5(71). DOI: 10.1186/s13568-0150154-z.

Martins, S.J., Rocha, J.A., Melo, H.C., Gerog, R.C., Ulhoa, C.J., Dianese, E.C., Oshiquiri, L.H., Cunha, M.G., Rocha, M.R., Araujo, L.G., Vaz, K.S., Dunlap, C.A. 2018. Plantassociated bacteria mitigate drought stress in soybean. Environmental Science and Pollution Research, 25, 1367613686. DOI: 10.1007/s11356-018-1610-5.

Melo, S.R., Zilli, J.E. 2009. Fixação biológica de nitrogênio em cultivares de feijão-caupi recomendadas para o Estado de Roraima. Pesquisa Agropecuária Brasileira, 44(9), 1177-1183. DOI: http://dx.doi.org/10.1590/S0100-204X2009000900016.

Noel, T., Sheng, C., Yost, C.K., Pharis, R.P., Hynes, M.F. 1996. Rhizobium leguminosarum as a plant growth promoting rhizobacterium: direct growth promotion of canola and lettuce. Canadian Journal of Microbiology, 42(3), 279-283. DOI: https://doi.org/10.1139/m96-040.

Paes, M.C.D, Pinho, R.G.V, Moreira, S.G. 2018. Soluções integradas para os sistemas de produção de milho e sorgo no Brasil, 21 a ed. ABMS-Associação Brasileira de Milho e Sorgo, Sete Lagoas.
Perrig, D., Boiero, M.L., Masciarelli, O.A., Penna, C., Ruiz, O.A., Cassan, F.D., Lunna, M.V. 2007. Plant growth promoting compounds produced by two agronomically important strains of Azospirillum brasilense, and their implications for inoculant formulation. Applied Microbiology and Biotechnology, 75, 1143-1150. DOI: 10.1007/s00253007-0909-9.

Reis Junior, F.B., Machado, A., Machado, C.T.T., Sodek, L. 2008. Inoculação de Azospirillum amazonense em dois genótipos de milho sob diferentes regimes de nitrogênio. Revista Brasileira de Ciência do Solo, 32(3), 1139-1146. DOI: 10.1590/S0100-06832008000300022.

Romeiro, R.S. 2007. Controle biológico de doenças de plantas: procedimentos. Viçosa, UFV.

Rothballer, M., Schmid, M., Fekete, A., Hartmann, A. 2005. Comparative in situ analysis of ipdC-gfpmut3 promotor fusions of Azospirillum brasilense strains Sp7 and Sp245. Environmental Microbiology, 7(11), 1839-1846. DOI: 10.1111/j.1462-2920.2005.00848.x.

Rozier, C., Gerin, F, Czarnes, S., Legendre, L. 2019. Biopriming of maize germination by the plant growthpromoting rhizobacterium Azospirillum lipoferum CRT1. Journal of plant Physiology, 237, 111-119. DOI: https://doi.org/10.1016/j.jplph.2019.04.011. 